\title{
Indolent Systemic Mastocytosis
}

National Cancer Institute

\section{Source}

National Cancer Institute. Indolent Systemic Mastocytosis. NCI Thesaurus. Code C9286.

An indolent mast cell neoplasm characterized by systemic infiltration of skin and internal organs by aggregates of neoplastic mast cells. There is no evidence of mast cell leukemia or clonal hematologic malignancy. Clinically, there is no evidence of palpable hepatomegaly and splenomegaly, malabsorption syndrome, or pathologic fractures. 